\title{
Correction to: Fraying Families: Demographic Divergence in the Parental Safety Net
}

\author{
Heeju Sohn ${ }^{1}$ \\ Published online: 29 August 2019 \\ (C) The Author(s) 2019
}

\section{Correction to: Demography (2019) 56:1519-1540 https://doi.org/10.1007/s13524-019-00802-5}

The original article has been corrected:

The article Fraying Families: Demographic Divergence in the Parental Safety Net written by Heeju Sohn, was originally published electronically on the publisher's internet portal (currently SpringerLink) on 1 July 2019 without open access. With the author(s)' decision to opt for Open Choice, the copyright of the article changed on August 2019 to (C) The Author(s) 2019 and the article is forthwith distributed under the terms of the Creative Commons Attribution 4.0 International License (http://creativecommons.org/licenses/by/4.0/), which permits use, duplication, adaptation, distribution, and reproduction in any medium or format, as long as appropriate credit is given to the original author(s) and the source, a link to the Creative Commons license is provided, and any changes that were made are specified.

Open Access This article is distributed under the terms of the Creative Commons Attribution 4.0 International License (http://creativecommons.org/licenses/by/4.0/), which permits unrestricted use, distribution, and reproduction in any medium, provided you give appropriate credit to the original author(s) and the source, provide a link to the Creative Commons license, and indicate if changes were made.

Publisher's Note Springer Nature remains neutral with regard to jurisdictional claims in published maps and institutional affiliations.

The online version of the original article can be found at https://doi.org/10.1007/s13524-019-00802-5

Heeju Sohn

hesohn@ucla.edu

1 California Center for Population Research, 337 Charles E. Young Drive, East, 4284 Public Affairs Building, CCPR, Los Angeles, CA 90095, USA 